\title{
The New "offline + Online" Teaching Model of College English Based on Cloud Computing
}

\author{
Liu Peng \\ Foreign Language and Economics School, Jiaozuo Normal College, Jiaozuo,Henan, China
}

\begin{abstract}
:
Through literature review, this paper expounds the descriptive parameter framework of College English mixed teaching and the index framework of teachers' effective teaching behavior in College English mixed teaching and its influencing factors. Based on this, this paper studies the new "offline + online" teaching model of College English based on cloud computing. This paper verifies and enriches the framework established based on literature through pilot interviews. For the part of effective teaching behavior, this paper applies Delphi expert survey method to conduct two rounds of questionnaire consultation with 10 information-based foreign language teaching research experts, and forms the final effective teaching behavior questionnaire. The results of this study show that teachers' effective teaching behavior in College English teaching can be summarized into five factors. According to the explanatory power, the order from high to low is: online learning management, teacher support, organizing face-to-face classroom, diversified evaluation and personalized teaching. Therefore, the new "offline + online" teaching model of College English based on cloud computing can improve the efficiency of English teaching.
\end{abstract}

Keywords: College English, Blended Teaching, Effective Teaching Behavior, Cloud Computing.

\section{INTRODUCTION}

Blended teaching "," blended learning "and" blended learning "are common Chinese translations of the English term blended learning, which are regarded as the same meaning in this study [1-2]. However, since this study mainly focuses on teachers and discusses teachers' teaching behavior, the term "hybrid teaching" is mainly used. Online learning has its own advantages, such as rich teaching resources, learning is not limited by time and place, which are unmatched by the traditional face-to-face classroom [3-4]. On the other hand, traditional faceto-face teaching also has its own advantages, such as easy to provide emotional support and so 
Article History: Received: 28 October 2021 Revised: 05 December 2021 Accepted: 10 January 2022 Publication: 28 February 2022

on [5].

Domestic educational technology circles have also emphasized the significance of mixed teaching. He Kekang, Li Kedong and Zhao Jianhua pointed out that blended teaching reflects the development of educational technology theory [6-8], not only reflects the characteristics of the information age, but also returns to the origin of learning, which will have a profound impact on the integration of information technology and curriculum. Nanguonong pointed out that hybrid teaching "conforms to the law of learning and teaching, is suitable for China's national conditions, and has practical significance for today's educational information construction and deepening reform".

The state emphasizes promoting educational modernization through educational informatization, and "the process of educational informatization has entered the in-depth development stage of emphasizing application, especially in the teaching process, from the initial stage of emphasizing the construction of software and hardware infrastructure". Hybrid teaching is the in-depth application of information technology and the product of the deep integration of information technology and curriculum.

\section{RESEARCH DESIGN AND DATA COLLECTION}

1.Pilot study

Pilot research refers to the preliminary research conducted by researchers to demonstrate whether the proposed theoretical assumptions are correct. It collects and analyzes data in the form of qualitative research. Its purpose is to provide theoretical and methodological support for later formal research.

According to the convenient conditions, relying on the author's personal relationship and introduction of acquaintances, open-ended interviews were conducted with 5 informatization foreign language teaching and research experts, 2 College English course directors, 9 College English course teachers and 5 non-English majors. The interview is mainly an interview, combined with wechat chat. All personnel participated in the interview with the author's invitation and consent.

\section{TABLE I. Pilot interview}

\begin{tabular}{|c|c|c|}
\hline $\begin{array}{c}\text { IDENTITY OF } \\
\text { VISITORS }\end{array}$ & $\begin{array}{c}\text { NUMBER OF } \\
\text { PEOPLE }\end{array}$ & MAIN INTERVIEW CONTENTS \\
\hline EXPERT IN & & $\begin{array}{c}\text { What are the advantages of blended College English } \\
\text { teaching? What are the requirements for teachers? } \\
\text { INFORMATION- } \\
\text { BASED } \\
\text { FOREIGN }\end{array}$ \\
LANGUAGE & 5 & What should teachers do? \\
\hline
\end{tabular}


Article History: Received: 28 October 2021 Revised: 05 December 2021 Accepted: 10 January 2022 Publication: 28 February 2022

\begin{tabular}{|c|c|c|} 
TEACHING & 2 & $\begin{array}{c}\text { How is blended College English Teaching } \\
\text { Implemented in your university? What are the } \\
\text { difficulties and challenges? What are the advantages } \\
\text { of this model? }\end{array}$ \\
\hline $\begin{array}{c}\text { HEAD OF } \\
\text { ENGLEGE } \\
\text { COURSE }\end{array}$ & 2 & $\begin{array}{c}\text { How do you implement blended teaching? What do } \\
\text { you think of this teaching model? What are the } \\
\text { advantages and disadvantages of this model? What } \\
\text { factors affect the exertion of its advantages? }\end{array}$ \\
\hline $\begin{array}{c}\text { COLLEGE } \\
\text { ENGLISH } \\
\text { TEACHER }\end{array}$ & 9 & $\begin{array}{c}\text { How did you learn this course? What do you think of } \\
\text { the mixed teaching model? What are the advantages } \\
\text { and disadvantages of this teaching model? What are } \\
\text { the expectations of College English teaching? }\end{array}$ \\
\hline STUDENT & 5 & \multicolumn{2}{c}{}
\end{tabular}

The five experts are associate professors or professors in Colleges and universities. They are information-based foreign language teaching. They have a doctorate in foreign language teaching in foreign language CSSCI, and many papers in research journals and educational CSSCI. At the same time, interviews were conducted with 2 College English course leaders, 9 College English teachers and 5 non-English majors from Shanghai, Zhejiang, Anhui, Yunnan and Hubei.

2.Formal research

The formation of teachers' teaching behavior is affected by many factors of themselves and external environment, which is a relatively complex process. Questionnaire survey and interviews involving many colleges and universities can better understand the current situation and influencing factors, but they can not deeply and systematically explore the action mechanism of various influencing factors. Therefore, this study adopts the method of case study, through in-depth interviews with three case teachers and the collection of various text and network materials, trying to explore the effective teaching behavior, influencing factors and influencing mechanism at a more detailed level.

TABLE II. Summary of study design

\begin{tabular}{|c|c|c|}
\hline RESEARCH & RESEARCH METHOD & DATA COLLECTION \\
QUESTIONS & MEANS \\
\hline $\begin{array}{c}\text { 1. What is the basic } \\
\text { situation of College } \\
\text { English blended teaching? }\end{array}$ & $\begin{array}{c}\text { Questionnaire and } \\
\text { interview }\end{array}$ & $\begin{array}{c}\text { Questionnaire and } \\
\text { interview }\end{array}$ \\
\hline
\end{tabular}


Article History: Received: 28 October 2021 Revised: 05 December 2021 Accepted: 10 January 2022 Publication: 28 February 2022

\begin{tabular}{|c|c|c|}
$\begin{array}{c}\text { 2. What is the current } \\
\text { situation of College } \\
\begin{array}{c}\text { English teachers' effective } \\
\text { teaching behavior in } \\
\text { blended teaching? }\end{array}\end{array}$ & $\begin{array}{c}\text { Questionnaire, Delphi } \\
\text { expert survey and } \\
\text { interview }\end{array}$ & $\begin{array}{c}\text { Questionnaire and } \\
\text { interview }\end{array}$ \\
\hline $\begin{array}{c}\text { 3. What factors affect } \\
\text { these behaviors? How do } \\
\text { these factors work? }\end{array}$ & $\begin{array}{c}\text { Questionnaire, interview } \\
\text { and case study }\end{array}$ & $\begin{array}{c}\text { Questionnaire, interview } \\
\text { and data collection }\end{array}$ \\
\hline
\end{tabular}

According to the convenience and accessibility, some teachers who participated in the questionnaire survey, the person in charge of College English courses in their department and the students in the class taught by the interviewing teachers were selected for interview in the school where the questionnaire was issued. The selection of interviewees takes into account the factors such as school, professional title and the type of mixed teaching, so as to ensure the diversity of research samples to a certain extent.

Some of the teachers interviewed were recommended by acquaintances and some were contacted by the author. Except for two teachers, the teacher interviews are individual interviews. The student interviews are all collective interviews, and the number of people interviewed each time is controlled within four, so as to ensure that each respondent has full discourse opportunities. Two teachers from different schools randomly selected several students from the teaching class, and the author interviewed them.

The interview conducted in the form of interview shall be conducted in the teachers' lounge or office. The time shall be agreed in advance and the quiet time shall be selected for the interview. During the interview, the author first obtained the consent of the respondents before starting the recording. The author conducted the interview according to the interview outline. When the respondents mentioned meaningful information that exceeded the interview outline, the author asked questions in due time. All interviews were recorded, and each interview lasted about 40-60 minutes. After the interview, transcribe the interview recording word by word to prepare for the subsequent interview data analysis. The school code is referred to by the initials of the school name.

\section{RESULTS AND DISCUSSION}

\section{Current situation of Blended Teaching in College English Course}

The survey data on the types of College English courses implementing blended teaching show that general English courses (EGP) account for 86.8\%, that is, in the College English curriculum system, blended teaching mainly occurs in general English courses. The reason is not difficult to understand. First, general English is still the mainstream in College English teaching, which is opened in all schools. Second, for other types of College English courses, 
Article History: Received: 28 October 2021 Revised: 05 December 2021 Accepted: 10 January 2022 Publication: 28 February 2022

many schools only teach face-to-face, and there is no online platform.

The statistical results show that the content of online learning has the characteristics of "multitasking", among which the top two and more than half are listening and writing exercises. This result is consistent with the statistical results of questions 1 and 2, and is also related to the nature of College English curriculum. College English Curriculum Requirements (02007) points out that college English Curriculum "takes English language knowledge and application skills, cross-cultural communication and learning strategies as the main contents", while the College English teaching guide, which has not been officially promulgated, points out that college English Curriculum "has both instrumental and humanistic properties". It can be seen that the cultivation of language skills is one of the main tasks of College English curriculum. The content of online learning is also related to the functions of the platform used.

As for the types of mixed teaching in College English courses, the most commonly used classification of mixed mode is based on the degree to which the functions and tasks of classroom learning are replaced by online mode. According to this division standard, type A is called additive type and type B is called mixed type in this study; Type $\mathrm{C}$ is called turnover transformation. According to the statistical results, $78 \%$ of them are additive type, and the sum of mixed and overturned type is only $22 \%$.

Figure 1 shows that $42.74 \%(n=162)$ of the tested teachers have received mixed teaching training, and $57.26 \%(\mathrm{n}=217)$ have not received training. Later, we will further analyze whether the training is related to the implementation of effective teaching behavior.

2.Current situation of effective teaching behavior in College English blended teaching

Firstly, all the data of the effective teaching behavior scale used for factor analysis were tested by kmo and Bartlett spherical test. The higher the kmo value, the more suitable for factor analysis. Kmo value above 0.9 is very suitable, 0.8-0.9 is suitable, 0.7-0.8 is general, and the minimum requirement shall not be less than 0.6. The kmo value of the effective teaching behavior scale is 0.928 , and the Bartlett sphere test also reaches the significant level $(\mathrm{P}<0.05)$, indicating that there is a factor structure, which is suitable for factor analysis. 
Article History: Received: 28 October 2021 Revised: 05 December 2021 Accepted: 10 January 2022 Publication: 28

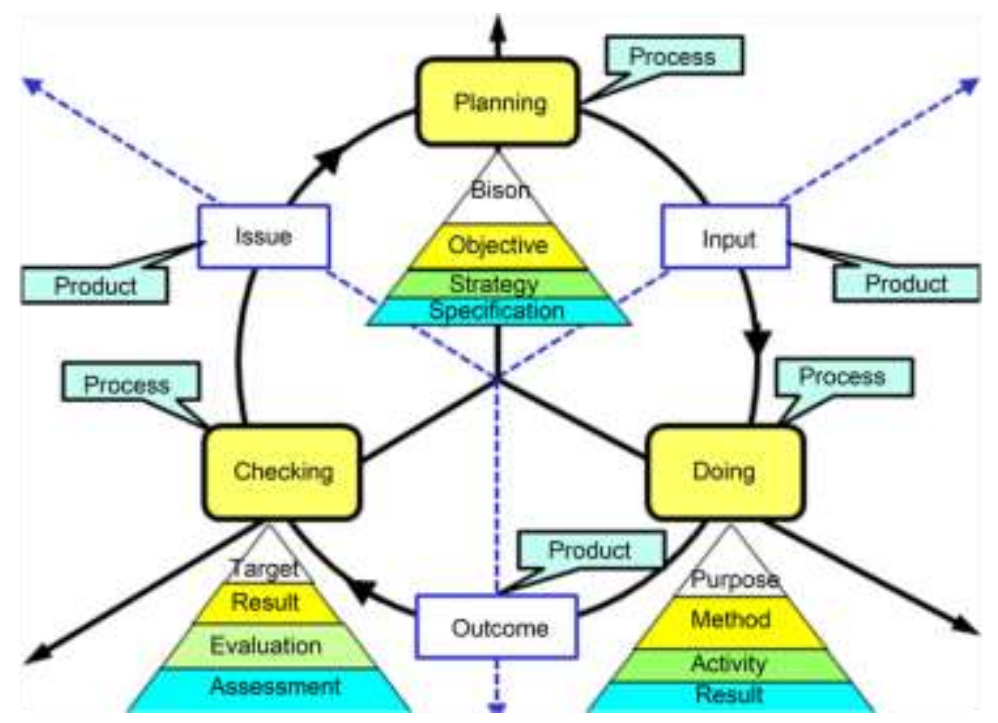

Fig 1: The basic framework of SPOC

The principal component analysis method is used to extract the factors, and the factors with eigenvalues greater than 1 are selected; The factor rotation method selects the maximum variance rotation method (varirnax), arranges the items according to the factor load, and only outputs the items whose load value is higher than 0.3. Six factors were extracted, and the cumulative interpretation variance was $61.635 \%$.

Next, all the items of each factor are combined into a new variable to analyze the differences of demographic variables, school types and school levels.

Firstly, the internal reliability of each factor is tested. Internal reliability refers to measuring the consistency between different items of the same concept. There are two methods of internal reliability test: half reliability and Cronbach alpha coefficient. In this study, Cronbach alpha coefficient is the most commonly used method in internal consistency reliability coefficient. The reliability test results are shown in Table 3. It is generally believed that the acceptable Cronbach alpha reliability coefficient should not be less than 0.70 . The cronbachalpha coefficients of the five factors of effective teaching behavior in College English blended teaching are more than 0.70 , indicating that the factors in the scale have good internal consistency. All variables of each factor were combined for subsequent analysis.

TABLE III. Cronbach alpha reliability coefficient of each factor

\begin{tabular}{|c|c|c|c|}
\hline $\begin{array}{c}\text { SERIAL } \\
\text { NUMBER }\end{array}$ & FACTOR NAME & $\begin{array}{c}\text { NUMBER OF } \\
\text { ITEMS }\end{array}$ & $\begin{array}{c}\text { ALPHA } \\
\text { COEFFICIENT }\end{array}$ \\
\hline 1 & Manage online learning & 9 & 0.898 \\
\hline
\end{tabular}


Article History: Received: 28 October 2021 Revised: 05 December 2021 Accepted: 10 January 2022 Publication: 28 February 2022

\begin{tabular}{|l|c|c|c|}
2 & Teacher support & 10 & 0.871 \\
\hline 3 & Organize face-to-face classes & 7 & 0.872 \\
\hline 4 & Diversified evaluation & 3 & 0.894 \\
\hline 5 & Individualized teaching & 3 & 0.733 \\
\hline
\end{tabular}

After combining all variables of each factor, the descriptive statistical analysis of each factor is as follows:

\section{TABLE IV. Descriptive analysis of each factor}

\begin{tabular}{|c|c|c|c|}
\hline $\begin{array}{c}\text { SERIAL } \\
\text { NUMBER }\end{array}$ & FACTOR NAME & M & SD \\
\hline 1 & Online learning management & 2.97 & 0.72 \\
\hline 2 & Teacher support & 3.83 & 0.55 \\
\hline 3 & Organize face-to-face classes & 3.49 & 0.69 \\
\hline 4 & Diversified evaluation & 2.89 & 0.97 \\
\hline 5 & Individualized teaching & 2.82 & 0.76 \\
\hline & Total effective teaching behavior & 3.33 & 0.54 \\
\hline
\end{tabular}

Among the five factors, the average value of teacher support factor is the highest $(\mathrm{M}=3.83)$. Teacher support belongs to the "traditional school" and "classic school" in Teachers' teaching behavior. 'teachers' teaching in any situation has teacher support, which is most familiar to teachers. Therefore, it is not difficult to understand why its average value is the highest. The average value of organizing face-to-face class is the second highest $(M=3.49)$. It can be seen that although most college English blended teaching can achieve face-to-face teaching and online part of the content, and teachers will supervise and evaluate online learning in face-toface class, it still fully realizes the transformation of classroom function. The online part only plays a convenient role for teachers and students because of the networking of after-school homework and the electronization of learning materials. The other three factors, online learning management, diversified evaluation and personalized teaching, can best reflect the characteristics of hybrid teaching, with the lowest score of less than 3 points.

\section{CONCLUSION}

As a response to the defects of single classroom teaching mode and single online learning mode, hybrid teaching has developed rapidly all over the world in recent years, especially in the 
Article History: Received: 28 October 2021 Revised: 05 December 2021 Accepted: 10 January 2022 Publication: 28 February 2022

field of higher education. Hybrid teaching combines information technology, Internet resources and education closely. However, technology and resources will not work automatically, and teachers are a key link restricting teaching quality. The purpose of this study is to construct an index framework of teachers' effective teaching behavior in College English blended teaching, to investigate the current situation of its implementation in some colleges and universities, and then to explore the main factors affecting these behaviors and the interactive relationship between them, so as to put forward suggestions for improving the quality of blended teaching.

\section{REFERENCES}

[1] Su Xiaohong, Zhao Lingling, Ye Lin, et al. Exploration and practice of Hybrid Teaching Based on MOOC + SPOC. Teaching in China University, 2015 (7): 60-65

[2] He bin, Cao Yang. SPOC: Innovation of teaching process based on MOOC. China audio visual education, 2015 (3): 22-29

[3] Zeng Mingxing, Li Guiping, Zhou Qingping, et al. From MOOC to SPOC: a deep learning mode construction. China audio visual education, 2015 (11): 28-34 + 53

[4] Chen Ran, Yang Cheng. Research on the design of SPOC blended learning mode. Distance education in China, 2015 (5): 42-47.

[5] Wang pengjiao, Duan Tingting, Cai Yunnan, et al. Application of SPOC based flipped classroom teaching design model in Open University. China audio visual education, 2015 (12): 179-186.

[6] Chen Yi, Zhao chengling. Teaching design and Application Research Based on flipped classroom model Modern educational technology, 2014, 24 (2): 49-54

[7] Li, D. , Zhang, Y. , \& Li, C. . (2019). Mining public opinion on transportation systems based on social media data. Sustainability, 11.

[8] Zhang, Y. X. , Feng, Y. X. , \& Yang, R. Q. . (2019). Network public opinion propagation model based on the influence of media and interpersonal communication. International Journal of Modern Physics B, 1950393. 